\title{
KELAYAKAN USAHA BUDIDAYA UDANG VANAME (Litopenaeus vannamei) DI DESA PURWOREJO, KECAMATAN PASIR SAKTI KABUPATEN LAMPUNG TIMUR
}

\author{
Muhammad Mutakin, Supono*1, Y.T. Adiputra*2
}

\begin{abstract}
Shrimp cultured in Purworejo Village begun in the 1980s. Productivity of shrimp farming in this region, had experienced a peak of success in 1998 with an average production of $200 \mathrm{~kg} / \mathrm{ha}$ with black tiger shrimp (Penaeus monodon) as the main commodity. Productivity decreases to $120 \mathrm{~kg} / \mathrm{ha}$ then occur due to decreasing environmental quality and susceptible post larvae to disease infections. One effort to increase the productivity of ponds can be done by switching the cultivation of black tiger shrimp to Pacific white leg (Litopenaeus vannamei) shrimp. The purpose of this study was to study the feasibility of semiintensive Pacific whiteleg shrimp cultured. This research was carried out in two shrimp farmer groups namely Sido Makmur and Lestari Gemilang located in Purworejo Village, Pasir Sakti District, East Lampung Regency. The type of research used is a case study and uses descriptive tests. The results showed that Pacific white leg shrimp cultured can produce 10,804,45 kg/3 ha and achieve a profit of $R$ p. 407.025.500 with a net B/C of 1,7. Moreover, black tiger shrimp culturehas reached $725 \mathrm{~kg} / 5$ ha with a profit of Rp. 13.660.000 with net B/C of 1,2. This study concluded semiintensive Pacific whiteleg shrimp is profitable compared toblack tiger shrimp cultured. It is also feasible to be developed by the village community.
\end{abstract}

Keywords: business analysis, white shrimp cultivation, East Lampung, coastal communities, productivi

\section{Pendahuluan}

Pada tahun 1980, petambak udang di Desa Purworejo Kecamatan Pasir Sakti Kabupaten Lampung Timur umumnya menerapkan sistem budidaya polikultur udang windu (Penaeus monodon) dan bandeng (Chanos chanos) secara ekstensif. Dengan polikultur diharapkan petambak memperoleh produk tambahan yang dihasilkan selain udang windu yaitu bandeng (Mahmud et al., 2007). Produktivitas udang windu di tambak Desa Purworejo pernah mengalami puncak produksi pada tahun 1998 sampai dengan tahun 2007 dengan produksi udang windu sebanyak $200 \mathrm{~kg} / \mathrm{ha}$ (Ristiyani, 2012). Pada tahun 2007 sampai dengan 2010

\footnotetext{
${ }^{1}$ E-mail: supono_unila@yahoo.com

2 Jurusan Perikanan dan Kelautan, Fakultas Pertanian, Universitas Lampung

Jl. Prof. S. Brodjonegoro No.1 Gedong Meneng Bandar Lampung, 35145
} 
produksi udang di Desa Purworejo ini mulai mengalami penurunan jumlah produktivitas menjadi $120 \mathrm{~kg} / \mathrm{ha}$ atau turun 40\% (Anshori, 2015).

Penurunan jumlah produksi udang windu di Desa Purworejo diduga akibat menurunnya kualitas lingkungan dan benur udang windu yang rentan terhadap infeksi penyakit. Salah satu upaya peningkatan produktivitas tambak dapat dilakukan dengan beralih budidaya yaitu budidaya udang windu beralih ke udang vaname (Litopenaeus vannamei) dengan meningkatkan teknologi budidaya kearah semi intensif. Beralihnya fungsi lahan budidaya dan peningkatan teknologi budidaya diharapkan dapat meningkatkan produksi dan pendapatan petambak di Desa Purworejo Kecamatan Pasir Sakti Kabupaten Lampung Timur Tujuan penelitian ini adalah untuk mempelajari kelayakan usaha budidaya udang vaname semi intensif pada lahan budidaya udang windu.Keberhasilan budidaya vaname tersebut dapat dianalisis dari analisa usaha, dan performa budidaya udang vaname yang di antaranya pertumbuhan, tingkat kelangsungan hidup, rasio konversi pakan dan biomasa.

\section{Metode}

Penelitian dilaksanakan selama 120 hari pada Januari sampai dengan April 2016 di tambak kelompok tani tambak udang yaitu Sido Makmur dan Lestari Gemilang yang terletak di Desa Purworejo, Kecamatan Pasir Sakti, Kabupaten Lampung Timur.Analisa usaha yang diamati berupa rasio $\mathrm{R} / \mathrm{C}$ yang merupakan rasioantara total penerimaan dengan total biaya yang dikeluarkan dalamkegiatan usaha(Kusumastanto, 2002). Performa budidaya udang vaname dianalisis dengan mengukur pertumbuhan, tingkat kelangsungan hidup (Goddard, 1996), rasio konversi pakan (Zonneveld et al., 1991) dan biomasa (Effendi, 2002).

Analisis data yang digunakan adalah analisis deskriptif kualitatif dan kuantitatif. Analisis kualitatif dilakukan berdasarkan data karakteristik responden. Sedangkan analisis kuantitatif digunakan untuk menganalisa keadaan statistik (Soekartawi, 2002)

\section{Hasil dan Pembahasan}

Penyebab petambak beralih membudidayakan udang vaname dengan teknologi semi intensif adalah banyaknya kendala dari budidaya udang windu mulai dari serangan penyakit, menurunnya kualitas lingkungan, kelangkaan bibit berkualitas yang menyebabkan banyak petambak gagal panen. Munculnya pemikiran untuk beralih ke tambak semi intensif didasari pada berhasilnya salah satu petambak yang membudidayakan udang vaname, bekerjasama dengan perusahaan perikanan terintegrasi. Yang disusul dengan adanya tambak percontohan di dua kelompok tani yaitu Sido Makmur dan Lestari Gemilang di saluran irigasi (parit) III Purworejo yang menjadi sarana menimba ilmu dan pengalaman dalam membudidayakan udang vaname.

Secara ekonomi beralihnya budidaya udang windu ekstensif menjadi udang vaname semi intensif sangat mempengaruhi karena adanya 
penyerapan jumlah pekerja yang cukup tinggi sehingga dapat mengurangi angka pengangguran yang ada. Berdasarkan informasi beralihnya budidaya udang windu ekstensif menjadi udang vaname semi intensif memberikan dampak yang cukup signifikan dari segi ekonomi, dimana dulunya tambak ekstensif per hektar hanya membutuhkan satu orang tenaga kerja, namun ketika banyak pemilik tambak yang mengubah tambak ekstensif mereka menjadi tambak semi intensif, tenaga kerja yang dibutuhkanantara $2-3$ orang.

Pemilik tambak pun merasa terbantu dengan adanya tenaga kerja yang telah mengelola tambaknya, dan menjadi salah satu faktor penentu keberhasilan dalam berbudidaya.
Dari hasil panen yang diperoleh pada 1 ha lahan tambak ekstensif yang diubah menjadi 4 petak tambak semi intensif ukuran $2.100 \mathrm{~m}^{2}$ mampu menghasilkan produksi udang sampai dengan 8 ton dengan size rerata 50 ekor/kg dengan omset mencapai 500 juta. Usaha perikanan yang dilakukan oleh seorang pengusaha atau pembudidaya harus menghasilkan keuntungan yang berkelanjutan. Halhal yang dapat mempengaruhi hasil penerimaan budidaya udang yaitu benur dan tenaga kerja (Utami et al., 2014). Investasi total usaha tambak udang windu yaitu Rp. 58.000.000, dengan nilai penyusutan sebesar Rp. 39.900.000, pada tambak udang vaname nilai investasi sebesar $\mathrm{Rp}$. 519.000.000, dengan nilai penyusutan sebesar Rp. 138.840.000 (Tabel 1).

Tabel 1. Perbandingan biaya investasi usaha tambak udang udang windu dan udang vaname.

\begin{tabular}{|c|c|c|c|c|}
\hline No & $\begin{array}{c}\text { Investasi Udang } \\
\text { Windu } \\
\end{array}$ & Jumlah & Harga Satuan (Rp) & Total Harga (Rp) \\
\hline 1 & Lahan & $5 \mathrm{Ha}$ & 7.000 .000 & $35.000 .000,-$ \\
\hline 2 & Diesel/Alkon & 5 & 2.500 .000 & 12.500.000,- \\
\hline 3 & Pompa Aksial & 5 & 1.800 .000 & 9.000.000,- \\
\hline 4 & Drum/Oblong & 5 & 100.000 & $500.000,-$ \\
\hline 5 & Serokan & 10 & 100.000 & $1.000 .000,-$ \\
\hline \multicolumn{4}{|c|}{ Jumlah Total } & Rp. 58.000.000,- \\
\hline No & $\begin{array}{c}\text { Investasi Udang } \\
\text { Vaname }\end{array}$ & Jumlah & Harga Satuan (Rp) & Total Harga (Rp) \\
\hline 1 & Lahan & $3 \mathrm{Ha}$ & 7.000 .000 & $21.000 .000,-$ \\
\hline 2 & Tambak & 8 & 20.000 .000 & 160.000.000,- \\
\hline 3 & Plastik Mulsa & 24 & 2.000 .000 & 48.000.000,- \\
\hline 4 & Kincir & 24 & 5.000 .000 & 120.000.000,- \\
\hline 5 & Genset & 2 & 50.000 .000 & 100.000.000,- \\
\hline 6 & Rumah Jaga & 2 & 15.000 .000 & 30.000.000,- \\
\hline 7 & Rumah Genset & 2 & 5.000 .000 & 10.000.000,- \\
\hline 8 & Anco & 8 & 50.000 & $400.000,-$ \\
\hline 9 & Timbangan & 2 & 100.000 & 200.000,- \\
\hline 10 & Jala & 4 & 700.000 & $2.800 .000,-$ \\
\hline 11 & Ember & 8 & 50.000 & $400.000,-$ \\
\hline 12 & Kabel & $300 \mathrm{~m}$ & 8000 & 2.400.000,- \\
\hline 13 & Bambu & 200 & 5000 & 1.000.000,- \\
\hline 14 & Lampu & 100 & 30.000 & $3.000 .000,-$ \\
\hline 15 & Pipa & 24 & 600.000 & 14.000.000,- \\
\hline 16 & Alkon/Diesel & 2 & $2.500 .000,-$ & 5.000.000,- \\
\hline
\end{tabular}




\begin{tabular}{rrrr}
17 & 8 & 100.000 & $800.000,-$ \\
\hline & Jumlah Total & Rp. 519.000.000,- \\
\hline
\end{tabular}

Investasi merupakan biaya tidak habis pakai dalam satu masa. Pada budidaya udang windu investasi yang digunakan ialah lahan, diesel / alkon, pompa aksial, serokan, dan drum/oblong. Investasi pada budidaya udang vaname meliputi, kincir, genset, plastik mulsa, rumah jaga, pipa pemasukan dan pengeluaran air, rumah genset, lampu, jala, kabel, bambu, drum/oblong, anco, ember dan timbangan.
Penyusutan merupakan biaya yang terdapat pada suatu alat dengan melihat nilai produksi, penyusutan tetap dikeluarkan walaupun suatu usaha tidak berproduksi lagi dalam hal ini biaya penyusutan alat. Penyusutan alat dapat terjadi karena pengaruh umur pemakaian. Biaya total variabel pada budidaya udang windu adalah sebesar Rp. 47.875.000, dan pada budidaya udang vaname sebesar Rp. 513.475.000 (Tabel 2).

Tabel 3. Perbandingan pendapatan dan keuntungan budidaya udang windu dan udang vaname

\begin{tabular}{|c|c|c|c|}
\hline Biaya Tetap & Investasi & Penyusutan & $\begin{array}{l}\text { Investasi - Nilai } \\
\text { Susut }\end{array}$ \\
\hline Biaya Tetap Udang Windu & $58.000 .000,-$ & 5.800 .000 & 52.200 .000 \\
\hline Biaya Tetap Udang Vaname & 519.000.000,- & 51.900 .000 & 467.100 .000 \\
\hline Biaya Total & Biaya Tetap & Biaya Variabel & Total Biaya (Rp) \\
\hline Biaya Total Budidaya Udang Windu & 5.800 .000 & 47.875 .000 & $\mathbf{5 3 . 6 7 5 . 0 0 0}$ \\
\hline Biaya Total Budidaya Udang Vaname & 51.900 .000 & 513.475 .000 & 565.375 .000 \\
\hline Nilai Produksi dan Harga & $\begin{array}{l}\text { Produksi } \\
\text { (Kg) }\end{array}$ & $\begin{array}{l}\text { Harga Satuan } \\
\text { (Rp) }\end{array}$ & $\begin{array}{l}\text { Jumlah Total } \\
\text { (Rp) }\end{array}$ \\
\hline Produksi Udang Windu & 725 & 75.000 & $\mathbf{5 4 . 3 7 5 . 0 0 0}$ \\
\hline Produksi Bandeng & 1080 & 12.000 & 12.960 .000 \\
\hline Produksi Udang Vaname & 10.804 .45 & 90.000 & 972.400 .500 \\
\hline Nilai Keuntungan & $\begin{array}{l}\text { Penerimaan } \\
\text { (TR) }\end{array}$ & $\begin{array}{l}\text { Biaya Total } \\
\text { (TC) }\end{array}$ & TR-TC \\
\hline Keuntungan Budidaya Udang windu & 67.335 .000 & 53.675 .000 & 13.660 .000 \\
\hline $\begin{array}{l}\text { Keuntungan Budidaya Udang } \\
\text { Vaname }\end{array}$ & 972.400 .500 & 565.375 .000 & 407.025.500 \\
\hline
\end{tabular}

Biaya penyusutan di atas terdiri dari biaya penyusutan alat yaitu lahan, tambak, plastik mulsa, kincir, genset, rumah jaga, rumah genset, anco, timbangan, jala, ember, kabel, lampu, pipa, alkon/diesel, drum/oblong, dan serokan.Data tersebut diperoleh dari hasil pengurangan total biaya investasi dikurang biaya penyusutan. Untuk hasil produksi udang windu dalam satu siklus dengan lahan seluas 5 ha diperoleh $725 \mathrm{~kg}$ udang dengan harga jual Rp. 75.000. Untuk produksi udang vaname semi intensif dalam satu siklus dengan lahan seluas 3 ha sebesar $10.804 .45 \mathrm{~kg}$ dengan harga jual Rp. 90.000. Dari hasil tersebutdiperoleh total keuntungan padausaha budidaya udang windu sebesar Rp. 13.660.000dan pada usaha budidaya udang vaname sebesar Rp. 407.025.500. 


\begin{abstract}
Studi kelayakan pada hakikatnya adalah untuk mendapatkan layak atau tidak layaknya suatu gagasan usaha, dengan kata lain studi kelayakan harus dapat memutuskan apakah suatu gagasan perlu diteruskan atau tidak. Perhitungan rasio $\mathrm{B} / \mathrm{C}$ budidaya udang windu dan budidaya udang vaname sebagai berikut:
\end{abstract}

Rasio B/C udang windu:

$\mathrm{B} / \mathrm{C}=$ Pendapatan $:$ Biaya Produksi

$=67.335 .000: 53.675 .000$

$=1,2$

Rasio B/C udang vaname:

$\mathrm{B} / \mathrm{C}=$ Pendapatan $\quad$ : Biaya Produksi

$=972.400 .500: 565.375 .000$

$=1,7$

Berdasarkan hasil di atas hasil perhitungan finansial unit usaha budidaya udang windu ekstensif sebesar 1,2. Sedangkan pada budidaya udang vaname semi intensif sebesar 1,7. Hasil analisis tersebut menunjukkan bahwa hasil rasio $\mathrm{B} / \mathrm{C}$ lebih besar dari 1 (satu), sehingga usaha budidaya udang vaname pada skala semi intensif layak untuk dikembangkan.

Pertumbuhan udang dapat diketahui dari pertambahan berat rerata udang hasil pengambilan contoh yang dilakukan setiap 7 hari sekali setelah umur pemeliharaan 35 hari. Dari perolehan hasil ini maka keseluruhan data kondisi pertumbuhan udang dapat diketahui (Hakim, 2017). Berdasarkan hasil pengambilan contoh selama pemeliharaan udang vaname di kelompok petambak Sido Makmur dan Lestari Gemilang, diperoleh hasil bobot rerata udang pada umur pemeliharaan 35 hari yaitu $1,6 \mathrm{~g}$ sampai dengan 2,8 g. Budidaya udang di panen seteleh udang mencapai target yang diinginkan, dalam penelitian ini lama masa pemeliharaan yaitu 105 hari sampai dengan 119 dengan capaian bobot 16,94 g sampai dengan 22,7 g (Tabel $4)$.

Tabel 4. Lama Pemeliharaan dan Berat Akhir Udang

\begin{tabular}{|c|c|c|c|c|c|c|c|c|c|}
\hline \multirow{2}{*}{\multicolumn{2}{|c|}{ Parameter }} & \multicolumn{8}{|c|}{ Petak Tambak } \\
\hline & & B1 & B2 & B3 & B4 & K1 & K2 & K3 & K4 \\
\hline Umur Pemeliharaan & & 117 & - & 117 & 113 & 105 & 108 & 113 & 119 \\
\hline Berat Akhir Udang (g & & 20,4 & - & 19,6 & 19,23 & 16,94 & 19,23 & 18,8 & 22,7 \\
\hline $\begin{array}{l}\text { Laju Pertumbuhan } \\
\text { (g/hari) }\end{array}$ & Harian & 0,21 & - & 0,20 & 0,22 & 0,22 & 0,24 & 0,22 & 0,24 \\
\hline
\end{tabular}

Pada petak B2 udang mengalami kematian pada umur dibawah 30 hari akibat serangan penyakit white spot syndrome virus (WSSV) sehingga tidak diperoleh data pertumbuhan. Menurut Yi et al. (2004), WSSV merupakan patogen yang paling serius menyerang udang dan telah menghancurkan industri perudangan di berbagai negara. Virus tersebut sangat ganas dan sangat sulit dihentikan (Chang et al., 1996), serta dapat menyebabkan kematian $100 \%$ udang peliharaan dalam waktu $3-10$ hari sejak gejala klinis muncul (Alifuddin et al., 2003)

Kelangsungan hidup (survival rate) atau SR udang berpengaruh terhadap nilai produksi udang budidaya. Tinggi rendahnya 
kelangusungan hidup dipengaruhi oleh kepadatan tebar, kualitas lingkungan dan penyakit. Biomasa merupakan total berat udang atau total produksi udang dalam satu siklus masa budidaya.
Biomasa terendah pada budidaya udang windu adalah pada petak tambak K4 yaitu $100 \mathrm{~kg}$ dan biomasa tertinggi adalah pada petak tambak B3 yaitu $200 \mathrm{~kg}$ (Gambar 1).

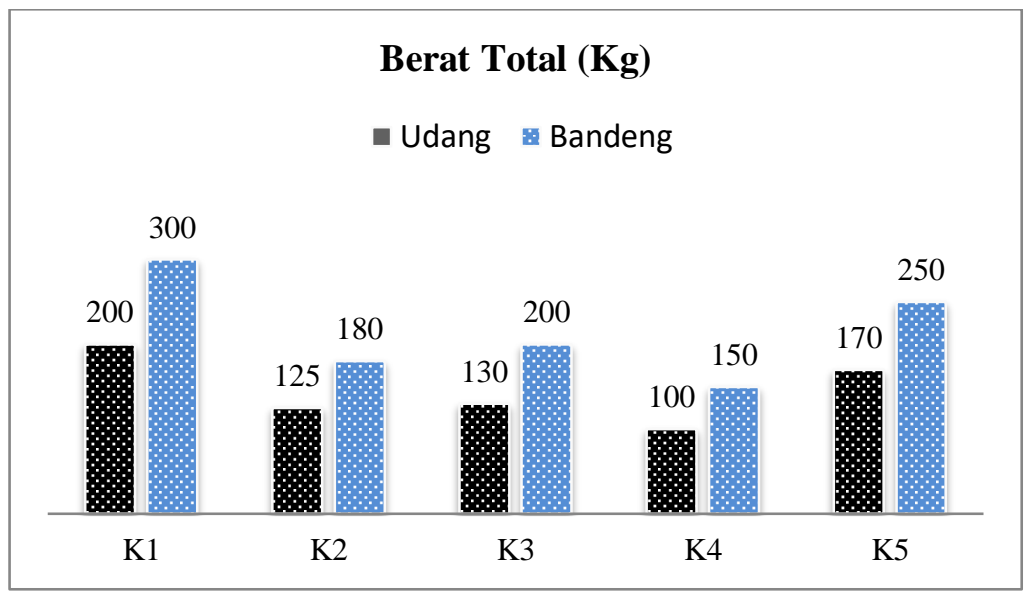

Gambar 1. Biomasa pada petakan tambakudang windu dan bandeng

Pada udang vaname biomasa terendah pada petak K4 kyaitu $1.225 \mathrm{~kg}$ dan biomasa tertinggi pada petak B3 yaitu $2.144,9 \mathrm{~kg}$ (Gambar 2).

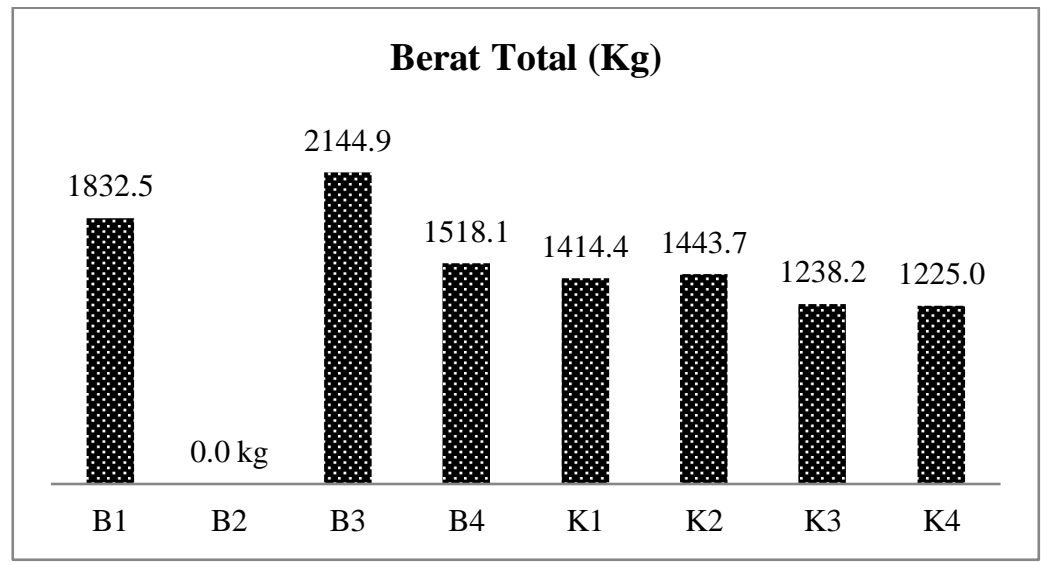

Gambar 2. Biomasa pada petakan tambak udang vaname

Tinggi rendahnya biomasa tergantung dari nilai berat udang ratarata saat panen dan tingkat kelulus hidupan udang. Semakin tinggi biomasa maka akan semakin baik karena akan berdampak pada pendapatan petambak.
Konversi pakan (feed conversion ratio) atau FCR dihitung pada akhir masa budidaya dengan membandingkan penggunaan pakan selama masa budidaya dan biomasahasil budidaya. Rasio konversi pakan terendah pada budidaya udang vaname yaitu pada 
petak B3 1.60, dan FCR tertinggi pada petak K1 1,49 (Tabel 5).

Tabel 5. Rasio konversi pakan budidaya udang vaname

\begin{tabular}{lcccccccc}
\hline \multirow{2}{*}{ Parameter } & \multicolumn{7}{c}{ Petak Tambak } \\
\cline { 2 - 9 } & B1 & B2 & B3 & B4 & K1 & K2 & K3 & K4 \\
\hline Komulatif Pakan Udang (Kg) & 3.457 & 0 & 3.499 & 3.297 & 3.524 & 3.256 & 3.066 & 2.888 \\
Total Produksi Udang (Kg) & $1.832,5$ & 0 & $2.144,9$ & $1.518,1$ & $1.414,4$ & $1.443,7$ & $1.238,2$ & 1.225 \\
Konversi Pakan (FCR) & 1,88 & - & 1,60 & 2,17 & 2,49 & 2,25 & 2,47 & 2,35 \\
\hline
\end{tabular}

Nilai FCR pada penelitian ini diatas angka maksimal yang disebutkan Supono dan Wardiyanto (2008) yaitu 1,4. FCR yang terlalu tinggi mengindikasikan terjadi kelebihan jumlah pemberian pakan (over feeding). Over feeding tidak selalu menyebabkan pertumbuhan udang tinggi namun tetap berdampak pada tingginya beban limbah akibat sisa pakan dan kotoran udang.

\section{Kesimpulan dan Saran}

Usaha budidaya udang vaname layak dikembangkan di Desa Purworejo, Kecamatan Pasir Sakti, Kabupaten Lampung Timur karena layak secara analisa usaha berdasarkan rasio $\mathrm{B} / \mathrm{C}$ sebesar 1,7. Performa budidaya udang vaname yang meliputi pertumbuhan, tingkat kelangsungan hidup, rasio konversi pakan dan biomasa lebih baik dibandingkan budidaya udang windu.

\section{Daftar Pustaka}

Alifuddin, M., Dana, D., Malole, M.B., dan Pararibu, F.H. 2003. Pathogenesis infeksi White Spot Syndrome Virus (WSSV) pada Udang Windu (Penaeus monodon). J Akuakultur Indonesia, 2: 85 - 92 .

Ansori, A. 2015. Analisis Kelayakan Tambak Udang Windu (Penaeus
Monodon) Ekstensif di Desa Purworejo Kecamatan Pasir Sakti Kabupaten Lampung Timur. Skripsi. Jurusan Budidaya Perairan, Fakultas Pertanian, Universitas Lampung, Bandar Lampung.

Chang, P., Lo, C., Wang, Y., Kou, H. 1996. Identification of White Syndrome Virus associated baculovirus target organs in the shrimp Penaeus monodon by in situ hybridization. Dis Aquat Organ, 27: 131 - 139.

Effendie, M. I. 1979. Metode Biologi Perikanan. Gramedia Pustaka Umum, Jakarta. 112 hal.

Hakim, L. 2017 Performa Budidaya Udang Vaname (Litopenaeus Vannamei) Semi Intensif di Desa Purworejo Kecamatan Pasir Sakti Kabupaten Lampung Timur. Skripsi. Jurusan Budidaya Perairan, Fakultas Pertanian, Universitas Lampung, Bandar Lampung. 17 hal.

Goddard S. 1996. Feed Management inIntensive Aquaculture. Chapman \& Hall, USA. 194 hal.

Kusumastanto, T. 2002. Reposisi Ocean Policy dalam Pembangunan EkonomiIndonesia di Era Otonomi Daerah. Orasi Ilmiah Guru Besar Tetap Bidang Ilmu Kebijakan Ekonomi Perikanan dan Kelautan. Fakultas Perikanan dan Ilmu 
Kelautan, Institut Pertanian Bogor, Bogor.134 hal.

Mahmud, U., Sumantadinata, K., dan Pandjaitan, N. 2007. Pengkajian Usaha Tambak Udang Windu Tradisional di Kabupaten Pinrang, Sulawesi Selatan. Jurnal MPI (2): 70-85.

Ristiyani, D. 2012. Evaluasi Kesesuaian Lahan Untuk Budidaya Perikanan Tambak Di Pesisir Kendal. Geo Image, 1(1): $12-18$.

Soekartawi. 2002. Prinsip Dasar Ekonomi Pertanian: Teori dan Aplikasi. PT Raja Grafindo Persada, Jakarta. 238 hal.

Supono dan Wadiyanto. 2008. Evaluasi Budidaya Udang Putih (Litopenaeus vannamei) dengan Meningkatkan Kepadatan Tebar di Tambak Intensif. Prosiding Seminar Hasil Penelitian \& Pengabdian kepada Masyarakat Universitas Lampung: 237 - 242.

Utami, R., Supriana, T., dan Ginting, R. 2014. Analisis Faktor-Faktor Yang Mempengaruhi Produksi Tambak Udang Sistem Ekstensif dan Sistem Intensif. Jurnal Sosial Ekonomi Pertanian dan Agribisnis, 3 (2): 1 - 10.

Yi, G. 2004. VP28 of Shrimp White Spot Syndrome Virus is involved in the attachment and penetration into shrimp cells. $J$ Biochem Mol Biol, 27: 726 - 734.

Zonneveld, N., Huisman, E.A., dan Boon, J.H. 1991. Prinsip prinsip Budidaya Ikan. PT Gramedia Pustaka Utama, Jakarta. 318 hal. 